\title{
Safety evaluation of defatted soybean particles after nanofabrication
}

\author{
Shenguang Tong ${ }^{1,2}$, Hongjiang Hao ${ }^{1,3}$, Xiaofei $\mathrm{Li}^{1,4}$, Hongbo $\mathrm{Li}^{1,5}$, Zhiyong Liao ${ }^{6}$, Zhihua $\mathrm{Wu}^{1,7 *}$, Hongbing Chen ${ }^{1,7}$ \\ ${ }^{1}$ State Key Laboratory of Food Science and Technology, Nanchang University, Nanchang, China; ${ }^{2}$ Hunan Prima \\ Pharmaceutical Research Center Co. Ltd., Changsha, China; ${ }^{3}$ Hanyi Biological Research and Development Center, \\ Beijing, China; ${ }^{4}$ ZheJiang Hyges Medical Nutrition and Technology Co. Ltd., Hangzhou, China; ${ }^{5} J i n g$ Brand Co., Ltd., \\ Huangshi, China; ${ }^{6}$ College of Life and Environmental Science, Wenzhou University, Wenzhou, China; ${ }^{7}$ Sino-German Joint \\ Research Institute, Nanchang University, Nanchang, China
}

"Corresponding Authors: Zhihua Wu, Sino-German Joint Research Institute, State Key Laboratory of Food Science and Technology, Nanchang University, No. 235 Nanjing Road East, 330047 Nanchang, China. Email: wuzhihua@ncu. edu.cn

Received: 26 May 2020 / Accepted: 22 July 2020 / Published: 14 August 2020

(c) 2020 Codon Publications

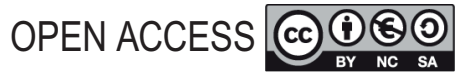

ORIGINAL ARTICLE

\begin{abstract}
Many nanoparticles are used in food for increasing the bioavailability of nutrients. Nano defatted soybean particles (nDSPs) were promising as nanoparticles of a traditional food, but its safety remains pending. In this work, the possible toxicity of nDSP was tested on cell and mouse models. Cell proliferation and the viability of defatted soybean particles (DSPs), DSP tracking in gastrointestinal, and tissue histopathological examination were performed. The Zeta potential of nDSP was as low as $-16 \pm 3 \mathrm{mV}$ and had no cytotoxicity on Caco- 2 cells or animal models. In the gastrointestinal tract, the nDSP showed similar absorption patterns with DSP of $500 \mathrm{~nm}$ or $1 \mu \mathrm{m}$. In acute toxicity assessment, no abnormal behavior was observed in mice after DSP administration, and no noticeable tissue damage and inflammatory lesion were found either. Here, we show that DSPs, including nDSP, are safe at a single dose of $10 \mathrm{~g} / \mathrm{kg}$ body weight, regardless of the particle size. The food property and aggregation behavior both help to make the nanoparticle safe.
\end{abstract}

Keywords: acute toxicity; cytotoxicity assay; gastrointestinal distribution; histopathological examination; nano defatted soybean particles; safety evaluation

\section{Introduction}

Nanomaterials are defined as materials sized between 1 and $100 \mathrm{~nm}$, generated by natural or engineering processes (Jeevanandam et al. 2018). In recent years, nanotechnology has progressed significantly, and it is being broadly used in textiles, electronics, cosmetics, and foods (Lanone and Boczkowski 2006). Nanoparticles (NPs) can be prepared in a specific manner, by modifying their size or other properties (Vance et al. 2015). The toxicity of NPs can be determined by their physicochemical properties and interaction with biological systems (Brenner et al. 2015; Leung et al. 2015). NPs are absorbed at higher levels than bulk chemicals through various routes, and they exhibit different toxicological profiles in vivo, compared to larger particles (Abudayyak et al. 2017; Boyles et al. 2016; Maurer et al. 2016). Given the popularity of NPs, the health risks and environmental effects they pose have attracted increasing attention (Graham et al. 2017; Pakrashi et al. 2017; van Pomeren et al. 2017).

Many NPs are used in food, drugs, skincare, and other consumer products (Bitencourt et al. 2016; Nohynek et al. 2008; Zhao and Castranova 2011). Similar to their medical application (Parhi and Suresh 2012), NPs are used in food to increase the bioavailability of nutrients (Zhao et al. 2010). For example, ergocalciferol is encapsulated in tripalmitin solid lipid NPs (Patel and 
San Martin-Gonzalez 2012). However, the safety of NPs, especially of those that can be uptaken directly, is a topic of great concern (Park et al. 2017; Wassef and Quadro 2011).

Food NPs are potentially a new kind of nanoparticulate carriers for drugs or nutrients, but their safety as a new NP remains uncertain. Nano defatted soybean particles (nDSPs) are defatted soybean particles (DSPs) with a diameter of $<100 \mathrm{~nm}$ (Wu et al. 2011), and they are milled from defatted soybean flour (DSF). As a traditional food, DSF is commercially available all over the world and is used extensively in food products (Lusas and Riaz 1995). Tracing an NP in tissues or organs is necessary to address the potential health and safety implications of nanomaterials used in nanomedicine (Zhao and Castranova 2011) As nDSP is composed of organic macromolecules without any traceable marker, either morphology or label, tracing nanofood particles in vivo is difficult. Fortunately, the digestion-resistant allergen in food offers a possibility for tracing the food particle.

In this work, the toxicity of nDSP with regard to its nanofabrication was tested in mouse and cell models. Using protein contained in soybean, especially $\beta$-conglycinin, the distribution of nDSP in the gastrointestinal tract of mice was localized and quantified.

\section{Materials and Methods}

\section{Materials}

The DSF was brought in from a local Agricultural Market. The Caco-2 cells were purchased from the Cell Bank of the Chinese Academy of Sciences (Shanghai, China), and Balb-c mice aged 4-5 weeks were purchased from the Institute of Occupational Medicine of Jiangxi Province (Nanchang, China, permission number "SCXK [Gan] 2014-0005"). Dulbecco's modified Eagle medium (DMEM) and rabbit monoclonal anti-soy protein antibody were from Sigma-Aldrich (PA, USA). The trypsin-EDTA, the CCK- 8 kit, and mouse $\beta$-conglycinin ELISA kits were brought from Sbjbio (Nanjing, China). The $20 \mathrm{~nm}$ gold conjugated polyclonal goat anti-rabbit IgG $(\mathrm{H}+\mathrm{L})$ was brought from Biodragon-Immunotech Co., Beijing, China.

\section{Method}

\section{Preparation of DSP}

The defatted soybean particles (DSPs) were prepared following the method described by Wu et al. (2011). In brief, DSF was dried and milled by FDV-SS ultra-fine crusher (Youqi Co., Taiwan, China) to about $1 \mu \mathrm{m}$ in diameter (ordinary DSP). These particles were then subjected to a PULVERISETTE 6 high-energy planetary ball mill (FRITSCH, Idar-Oberstein, Germany) at a rotation speed of $450 \mathrm{rpm}$, with the ratio of stainless steel ball:mass at 10:1 in a stainless steel bowl. During different milling times, DSPs of 100 and $500 \mathrm{~nm}$ in dimeter were prepared in $8 \mathrm{~h}$ and $4 \mathrm{~h}$, respectively.

\section{Characterization of DSP}

For particle characterization, the DSPs were diluted in distilled water at $0.5 \mathrm{mg} / \mathrm{mL}$ as stock solution. These solutions were sonicated in a 650-92 Ultrasonic homogenizer (Biosafer, Hong Kong, China) before characterization. A laser particle size analyzer (Nano ZS90, Malvern, UK) was used to determine the hydrodynamic sizes and the surface zeta potential ( $\zeta$ potential) of DSPs at $25^{\circ} \mathrm{C}$. A JSM 6701F scanning electron microscope (SEM) (JEOL, Japan) was used to observe the size and morphology of DSPs. A drop of DSP solution was placed on a slide and dried at room temperature. Subsequently, the samples were coated with gold-palladium, observed, and photographed. The Feret diameter (intended as the larger diameter of the NP projection) was used to characterize the size of DSPs (Recordati et al. 2016).

\section{Caco-2 cell viability}

Caco-2 cells were maintained in DMEM at $37^{\circ} \mathrm{C}$ under an atmosphere containing $5 \% \mathrm{CO}_{2}$. The growth medium was changed daily in the first a few weeks, followed by replacement of the medium thrice a week. The cells were subcultured weekly by trypsin-EDTA treatment (Lacroix et al. 2017; Ma et al. 2013).

The effect of DSP on cell proliferation and the viability of Caco- 2 cells were measured via CCK-8 assay (Lacroix et al. 2017; Qu et al. 2017). Caco-2 cells were seeded in 96-well culture plates at a density of 5000 cells per well in volume of $100 \mu \mathrm{L}$ and allowed to adhere overnight. The cells were then treated with different concentrations (50,100, 200, 400, and $800 \mu \mathrm{g} / \mathrm{mL})$ of DSP $(100 \mathrm{~nm}, 500 \mathrm{~nm}$, and $1 \mu \mathrm{m})$. After incubation for $24 \mathrm{~h}$, the medium with samples was replaced by $100 \mu \mathrm{L}$ of new DMEM medium and $10 \mu \mathrm{L}$ of CCK- 8 solution. Following $4 \mathrm{~h}$ of incubation, the optical density (OD) value of each well was measured using the Model 1860 absorbance microplate reader (Bio-Rad, CA, USA) at a wavelength of $450 \mathrm{~nm}$. Inhibition of cell growth was calculated by the percentage of viable cells compared with the untreated control. Cell viability $(\%)=(\mathrm{OD}$ of experimental sample/OD of positive control sample) $\times 100 \%$.

\section{In vivo experiments}

Animals. Female and male Balb-c mice were acclimated to the environment for 2 weeks prior to the initiation of 
the study and fed with soybean-free food. The environmental conditions were set at $22^{\circ} \mathrm{C} \pm 2{ }^{\circ} \mathrm{C}$, relative humidity of $55 \% \pm 10 \%$, and a $12 \mathrm{~h} \mathrm{light/dark} \mathrm{cycle.}$

Tissue sampling. To determine the time dependence of the gastrointestinal absorption of nDSP in different sizes, the mice $(\mathrm{N}=80)$ were orally administered with $\mathrm{nDSP}$ of different sizes (100 nm, $500 \mathrm{~nm}$, and ordinary DSP), at a single dose of $100 \mathrm{mg}$, and with fluorescent microspheres (positive control) at a single dose of $10 \mu \mathrm{g}$. The control group was treated with distilled water by oral gavage. Following the above treatments, each group of mice was sacrificed at various time intervals $(0.5,1,2$, and $4 \mathrm{~h}$; four mice per time period). The body weight (BW) of each mouse was measured immediately after they were sacrificed. The stomach, duodenum, jejunum, ileum, colon, and rectum were collected for DSP quantification, and the duodenum, jejunum, and ileum were used to investigate DSP distribution and location. All collected tissues were rinsed with ice-cold phosphate buffer saline (PBS, $0.01 \mathrm{M}, \mathrm{pH}$ 7.4) to remove excess blood and chyme thoroughly, and the tissues were weighed. For DSP quantification, the collected tissues were stored at $-80^{\circ} \mathrm{C}$ for subsequent analysis. A portion of collected tissues was fixed in 4\% paraformaldehyde for histological examination and location of DSP.

Determination of DSP content. The DSP concentration in the gastrointestinal tract was quantified by ELISA, according to the instructions of the manufacturer. Before ELISA analysis, gastrointestinal tract samples were homogenized in $0.01 \mathrm{M}$ (pH 8.0) Tris- $\mathrm{HCl}(1: 10, \mathrm{~m} / \mathrm{v})$. The homogenates were mixed in a shaker for $1 \mathrm{~h}$. The homogenates were centrifuged for $10 \mathrm{~min}$ at $3000 \mathrm{r} / \mathrm{min}$ to obtain the supernatant for analysis. In particular, the concentration $\left(\rho_{1}\right)$ of $\beta$-conglycinin, mass fraction (w) of $\beta$-conglycinin in $\mathrm{nDSP}$ (L'Hocine and Boye 2007; Wang et al. 2014), total weight of each organ (M) of each mouse, and total extract volume $\left(\mathrm{V}_{1}\right)$ of each part of the gastrointestinal tract were measured. The concentration $\left(C_{1}\right)$ of DSP was then calculated using the following equation:

$$
\mathrm{C}_{1} /(\mu \mathrm{g} / \mathrm{mg})=\frac{\left(\rho_{1} \times \mathrm{w}\right) \times \mathrm{V}_{1}}{\mathrm{M}}
$$

In addition, the concentration of fluorescent microspheres in the gastrointestinal tract was quantified by Varioskan ${ }^{\circledast}$ Flash Spectral Scanning Multimode Reader (Thermo Fisher, MA, USA). The concentration $\left(\rho_{2}\right)$ of fluorescent microspheres, total weight of each organ (M), and total extract volume of each part of the gastrointestinal tract $\left(\mathrm{V}_{2}\right)$ were measured. The concentration $\left(\mathrm{C}_{2}\right)$ of fluorescent microspheres was then calculated by the following equation:

$$
\mathrm{C}_{2} /(\mu \mathrm{g} / \mathrm{mg})=\frac{\rho_{2} \times \mathrm{V}_{2}}{\mathrm{M}}
$$

\section{Tracking of DSP}

Immunohistochemistry

To analyze the distribution and location of DSP in the gastrointestinal tract of each mouse, immunogold silver staining (IGSS) was performed on frozen sections (Frey et al. 1996; Jani et al. 1992; Tang et al. 2005). For IGSS, gastrointestinal frozen sections were immunostained with rabbit monoclonal anti-soy protein antibody. Secondary antibody, namely, $20 \mathrm{~nm}$ gold conjugated polyclonal goat anti-rabbit IgG, was then added. After immuno-colloidal gold labeling, the DSP was observed in frozen sections under a light Axio vert A1 microscope (Carl Zeiss, Jena, Germany) for the identification of its location in the small intestine. The cellular location of DSP was visible as black granular pigments.

DSPs in the gastrointestinal tissue were quantified by measuring the integrated optical density (IOD) of immunoreactive staining. Specific black staining was selected. The IODs at the site of the mucosa, villus, and crypt from different gastrointestinal tissues were estimated using Image-Pro Plus 5.0 software. The image analysis conditions were corrected using the IODs of corresponding negative control for each experimental group.

\section{Immunoelectron microscopy}

Immunoelectron microscopy was conducted to further investigate the location and pathway of DSP uptake across the gastrointestinal tract. Representative portions of the duodenum, jejunum, and ileum were fixed in $2 \%$ glutaraldehyde and $2 \%$ formaldehyde in $0.1 \mathrm{M}$ PBS for $4 \mathrm{~h}$ at $4^{\circ} \mathrm{C}$. Samples were then rinsed with buffer, dehydrated through a graded ethanol series, and embedded in LR White. Ultrathin sections of $50 \mathrm{~nm}$ were cut and mounted on copper grids. Sections were blocked with $1 \%$ bovine serum albumin (BSA) for $20 \mathrm{~min}$ at room temperature and then incubated overnight at $4^{\circ} \mathrm{C}$ with anti-soybean protein primary antibody. Following the addition of primary antibody, the samples were rinsed thrice in $0.01 \mathrm{M} \mathrm{PBS}$ (pH 7.4). Following treatment with $1 \% \mathrm{BSA}$, sections were incubated with $10 \mathrm{~nm}$ colloidal gold-labeled goat anti-rabbit IgG (Sigma-Aldrich, PA, USA) and washed with $0.01 \mathrm{M}$ PBS. Finally, sections were stained sequentially with uranyl acetate for $30 \mathrm{~min}$ and lead nitrate for $6 \mathrm{~min}$. The ultrastructural distribution of nDSP was observed with Tecnai 12 Transmission Electron Microscope (TEM, FEI Co., Hillsboro, USA). ImagePro Plus 6.0 software (Media Cybernetics, UK) was used to calculate the number of positive signals (Jia et al. 2012; Li et al. 2017).

Histopathological examination. For histological examination, representative portions of the stomach and the small intestine were fixed in $10 \%$ neutral buffered formalin for at least $24 \mathrm{~h}$ at room temperature. The fixed samples were 
routinely processed for paraffin embedding, sectioned at $8-10 \mu \mathrm{m}$ thickness, stained with hematoxylin-eosin (H\&E), and observed under a light Axio vert A1 microscope (Carl Zeiss, Jena, Germany).

Signs and symptoms, relative organ body weight. After acclimation, the mice were randomly divided into four groups (10 mice in each group). Three groups of mice were orally administered with DSP of different sizes $(100 \mathrm{~nm}, 500 \mathrm{~nm}$, and $1 \mu \mathrm{m})$, at a single dose of $10 \mathrm{~g} /$ $\mathrm{kg}$ BW. The control group was treated with distilled water. Immediately after treatment, the general health and behavior of mice were monitored. The BW of each mouse was measured at sacrifice. The mice were euthanized $24 \mathrm{~h}$ after the treatment and subjected to exsanguination by heart perfusion. After drawing blood from the heart, the mice underwent complete necropsy (Recordati et al. 2016). The organ weight was measured, and relative organ weights (\%) were calculated as wet organ weight/ total BW .

Statistical analysis. All data were reported as the mean with standard deviation (SD) for at least three replicates of each group. All statistical analyses were conducted using one-way analysis of variance (ANOVA) followed by post-hoc comparisons using Tukey's or Dunnett's multiple comparisons test. P-values less than 0.05 were considered significant.

\section{Results}

\section{Characterization of DSP}

The size distribution of DSP in water is shown in Figure 1d. Ordinary DSP $(1 \mu \mathrm{m})$ showed a bimodal size distribution and broad peaks. Monomodal distributions were observed for 500 and $100 \mathrm{~nm}$ DSP. Scanning electron microscope (SEM) results showed that $1 \mu \mathrm{m}$ DSP samples exhibited irregular clusters, $500 \mathrm{~nm}$ samples were composed of nanosheets, and $100 \mathrm{~nm}$ DSP samples became spherical geometry (Figure 1a-1c). The hydrodynamic diameters of these particles in solvent were consistent with the particle sizes observed in the SEM images.

The hydrodynamic diameter and $\zeta$-potential of each DSP in deionized water $\left(\mathrm{DI} \mathrm{H}_{2} \mathrm{O}\right)$ were characterized by a laser particle size analyzer (Table 1). It was found that all tested DSPs exhibited a negative $\zeta$ potential in DI $\mathrm{H}_{2} \mathrm{O}$. The $\zeta$ potential of $1 \mu \mathrm{m}$ DSP was $-33 \pm 2 \mathrm{mV}$, but the $\zeta$
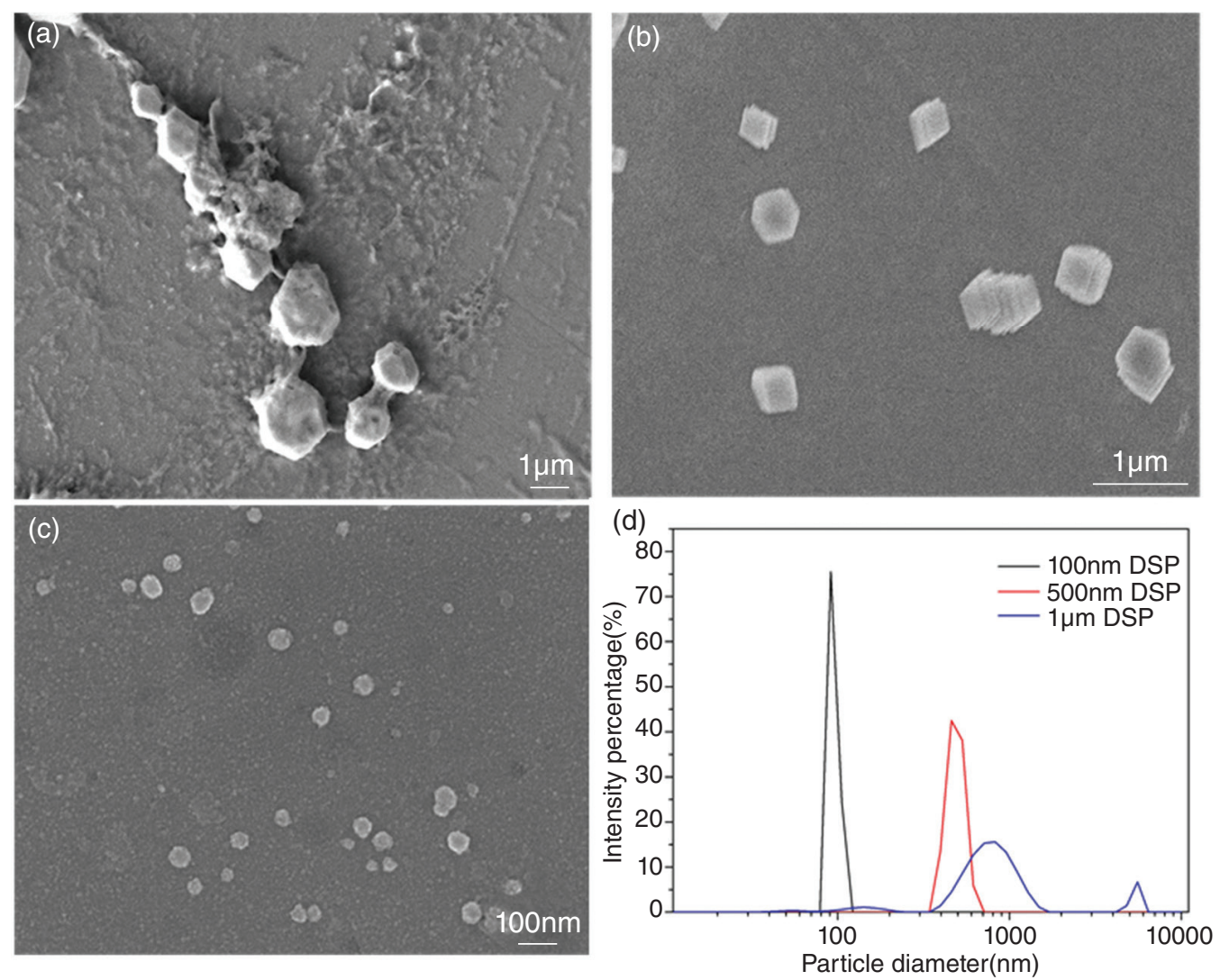

Figure 1. Representative scanning electron micrographs of defatted soybean particle (DSP)-1 $\mu \mathrm{m} \mathrm{(a),500} \mathrm{nm} \mathrm{(b),} \mathrm{and}$ $100 \mathrm{~nm}$ (c); laser particle size analyzer data (d) showing the hydrodynamic size of DSP. 
Table 1. Main physicochemical properties of nDSP and ordinary DSP.

\begin{tabular}{lcccccc} 
& Zetasizer Nano ZS & TEM & Zetasizer Nano ZS & $\begin{array}{c}\text { Mass concentration } \\
(\mathrm{mg} / \mathrm{mL})\end{array}$ & Solvent \\
\cline { 2 - 4 } & $\begin{array}{c}\text { Hydrodynamic Diameter } \\
(\text { mean } \pm \text { SD) }(\mathrm{nm})\end{array}$ & $\begin{array}{c}\text { Diameter } \\
(\text { mean } \pm \text { SD) }(\mathrm{nm})\end{array}$ & Zeta potential $(\mathrm{mV})$ & & 0.5 & Distilled water \\
\hline $100 \mathrm{~nm}$ DSP & $95 \pm 9$ & $79 \pm 21$ & $-16 \pm 3$ & $-19 \pm 1$ & 0.5 & Distilled water \\
$500 \mathrm{~nm}$ DSP & $433 \pm 65$ & $415 \pm 82$ & $-33 \pm 2$ & 0.5 & Distilled water \\
Ordinary DSP & $1134 \pm 224$ & $1138 \pm 139$ & & & \\
\hline
\end{tabular}

ZS. Nano ZS is type name of Zetasizer, or particle size analyzer.

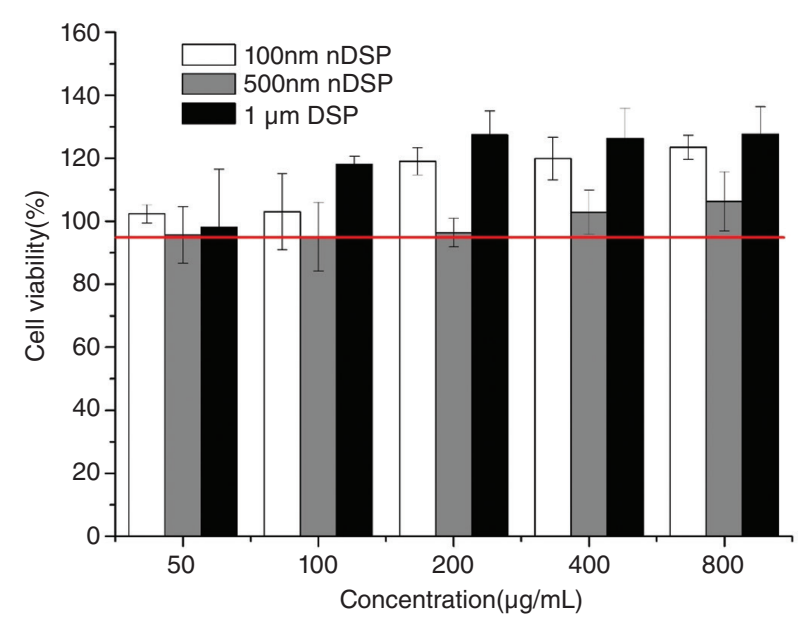

Figure 2. Cell viability (\%) of Caco-2 cells after exposure to given concentrations of $100 \mathrm{~nm}, 500 \mathrm{~nm}$, and $1 \mu \mathrm{m}$ of DSP. The red line indicates that the cell viability is $95 \%$.

potential of 100 and $500 \mathrm{~nm}$ DSPs was $-16 \pm 3$ and $-19 \pm$ $1 \mathrm{mV}$, respectively. Previous studies have demonstrated that electrostatic stabilization of NPs typically require a $\zeta$ potential above $30 \mathrm{mV}$ or below $-30 \mathrm{mV}$ (Bihari et al. 2008). This result suggested that 100 and $500 \mathrm{~nm}$ DSPs were of low stability in aqueous solution.

\section{Cell viability}

The effect of each DSP on the viability of the undifferentiated Caco- 2 cells was determined using the CCK- 8 assay. As shown in Figure 2, the data illustrated that all tested DSPs had no cytotoxicity on the Caco-2 cells at the concentration used. Upon exposure to DSPs, the cell viability slightly increased when the addition level (50$800 \mu \mathrm{g} / \mathrm{mL}$ ) gradually increased.

\section{Gastrointestinal tract distribution}

The distribution and localization of DSP in the gastrointestinal tract within different time periods $(0.5,1,2$, and $4 \mathrm{~h}$ ) after intragastric gavage were evaluated by sandwich ELISA and IGSS.

Figure 3 summarizes the concentrations of DSP found in the digestive tract. For each DSP, regardless of particle size, the contents of DSP in the small intestine were consistently high (Figure 3a-3c). The small intestine consistently had the highest concentrations of all DSPs. After $4 \mathrm{~h}$ of intragastric gavage administration, no significant differences were found among the contents of all DSPs (Figure 3a-3c). In the large intestine, after $4 \mathrm{~h}$ of intragastric gavage administration, the total contents of $1 \mu \mathrm{m}$ DSP, $500 \mathrm{~nm}$ DSP, and $100 \mathrm{~nm}$ DSP were $0.82 \pm$ $0.16,0.48 \pm 0.06$, and $0.45 \pm 0.06 \mu \mathrm{g} / \mathrm{mg}$, respectively (Figure 3a-3c). The total content of 100 and $500 \mathrm{~nm}$ DSPs in the large intestine were very significantly lower than that of $1 \mu \mathrm{m}$ DSP $(\mathrm{P}<0.01)$.

In this study, the maximum contents of $100 \mathrm{~nm}$ DSP, $500 \mathrm{~nm}$ DSP, and $1 \mu \mathrm{m}$ DSP were reached at 1,2 , and $2 \mathrm{~h}$, respectively (Figure $3 \mathrm{~d}$ ), indicating that small particles reached the gastrointestinal tract rapidly. The maximum total content of $100 \mathrm{~nm}$ DSP, $500 \mathrm{~nm}$ DSP, and ordinary DSP in the gastrointestinal tract was $2.43 \pm 0.01,2.86 \pm$ 0.04 , and $2.05 \pm 0.14 \mu \mathrm{g} / \mathrm{mg}$, respectively.

Before localization of each DSP, the gastrointestinal tract was evaluated histologically. As shown in Figure 4, no noticeable tissue damage or inflammatory lesion were found in the gastrointestinal tracts of all DSP-treated mice.

The distribution of each DSP in the small intestine was analyzed by IGSS. In DSP-treated mice, regardless of the particle size, IGSS revealed the presence of DSP in the intestinal villi, epithelial cells, and mucosa of the small intestine (Figure 5 and Supplementary Figures S1-S3). Sections of the positive control group-exposed mice showed the same distribution of FM in the small intestine (Supplementary Figure S4). Tissue from the control animals showed no staining, which proved that no unspecific staining occurred.

The subcellular localization of nDSP in the small intestine of mice was investigated by IEM. For all tested 
(a)

(c)
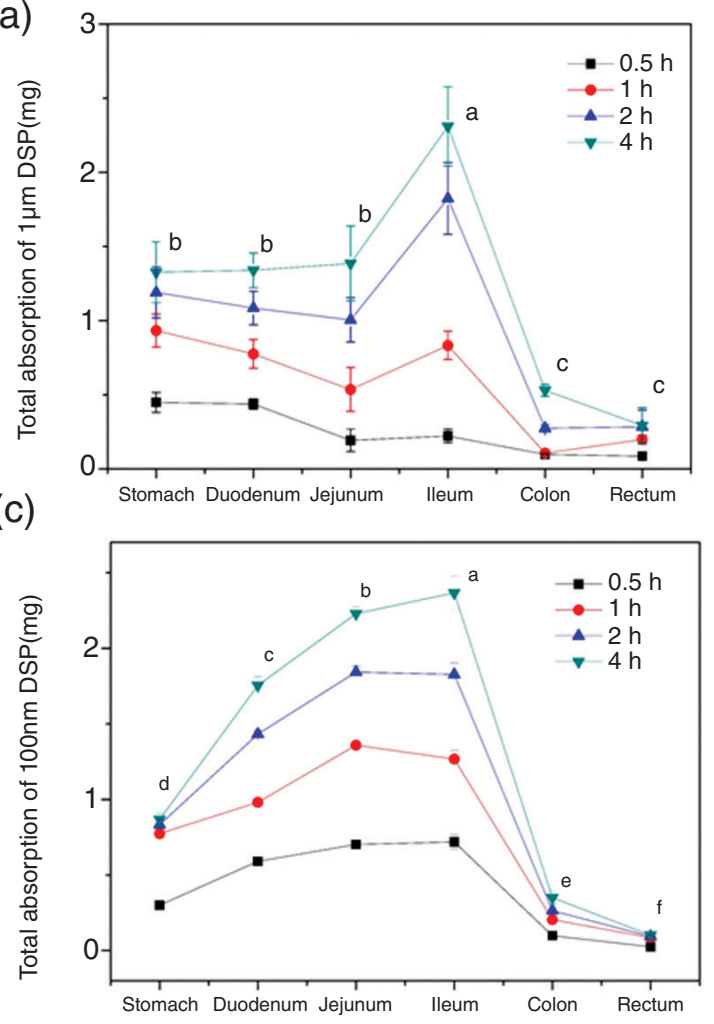

(b)

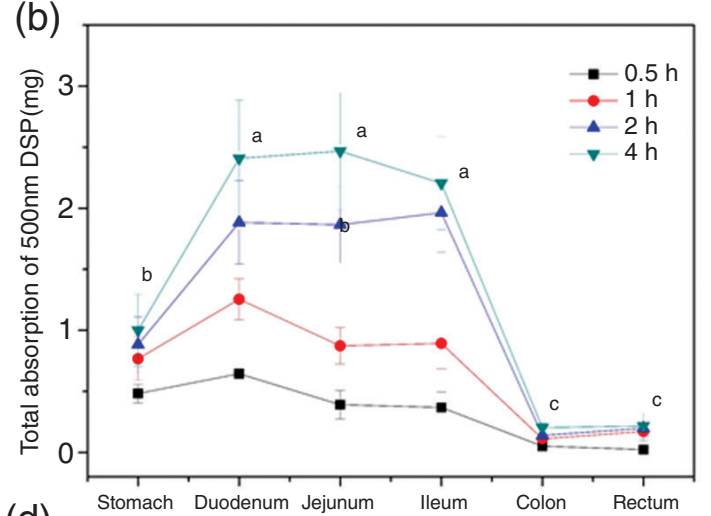

(d)

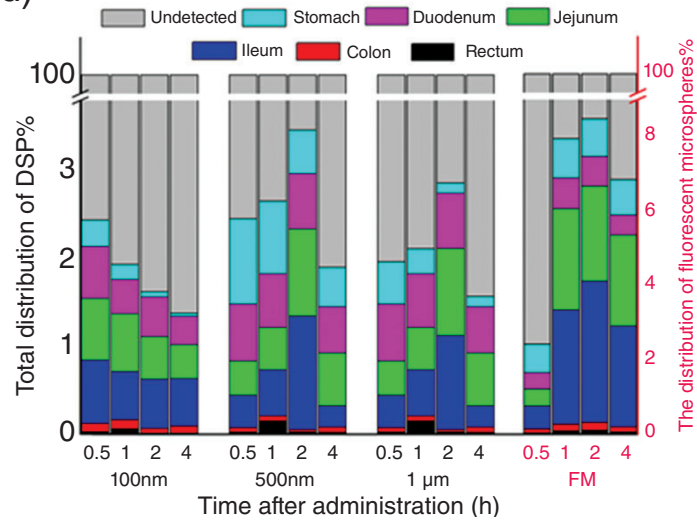

Figure 3. The distribution of DSP in gastrointestinal tract. (a) $1 \mu \mathrm{m}$ DSP; (b) $500 \mathrm{~nm}$ DSP; (c) $100 \mathrm{~nm}$ DSP; and (d) the percentage distributions of each DSP and fluorescent microspheres (FM) in the gastrointestinal tract. Different letters indicate statistical differences among the different parts of the gastrointestinal tract at $4 \mathrm{~h}(\mathrm{P}<0.05)$.

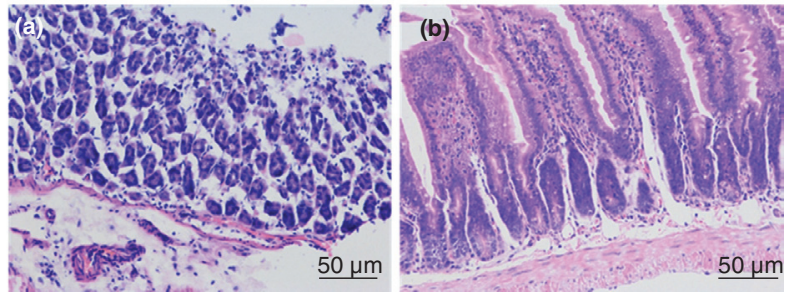

Figure 4. Hematoxylin-eosin staining of gastrointestinal tract. (a) stomach; (b) jejunum. No noticeable tissue damage or inflammatory lesion were found in the gastrointestinal tracts of all DSP-treated mice.

DSP-treated mice, mostly spherical, electron-dense granules were found within the cytoplasm of epithelial cells. Rarely, small numbers of DSP are found within the tight junction (Supplementary Figure S5). The semiquantitative analysis of different sizes of DSP-positive staining in the small intestine was performed through the number of positive signals using Image-Pro ${ }^{\oplus}$ Plus software. As shown in Figure 6, regardless of the particle size of DSP, semiquantitative analysis revealed significantly more DSP-positive signals in transcellular transport, compared to paracellular transport $(\mathrm{P}<0.01)$. In terms of DSPpositive signals in transcellular transport, no significant differences were found among $100 \mathrm{~nm}$ DSP, $500 \mathrm{~nm}$ DSP, and $1 \mu \mathrm{m}$ DSP. By contrast, in paracellular transport, the number of $100 \mathrm{~nm}$ DSP-positive signals was significantly higher than that of $500 \mathrm{~nm}$ DSP and $1 \mu \mathrm{m}$ DSP $(\mathrm{P}<0.05)$.

\section{Acute toxicity}

Mice were administered with DSP $(100 \mathrm{~nm}, 500 \mathrm{~nm}$, and $1 \mu \mathrm{m}$ ) via intragastric gavage at a single dose of 10 $\mathrm{g} / \mathrm{kg} \mathrm{BW}$, whereas the control group was treated with DI $\mathrm{H}_{2} 0$. Mice were euthanized $24 \mathrm{~h}$ after the treatment. The BW of each mouse was measured before treatment and at sacrifice. Organs were collected for histological examination.

After administration of each DSP $(100 \mathrm{~nm}, 500 \mathrm{~nm}$, and $1 \mu \mathrm{m})$ and during the following hours, all mice appeared healthy and no abnormal behavior was observed. At sacrifice, no significant differences in BW gain and relative organ weight were recorded among those DSPs groups. Moreover, no significant differences were observed in 


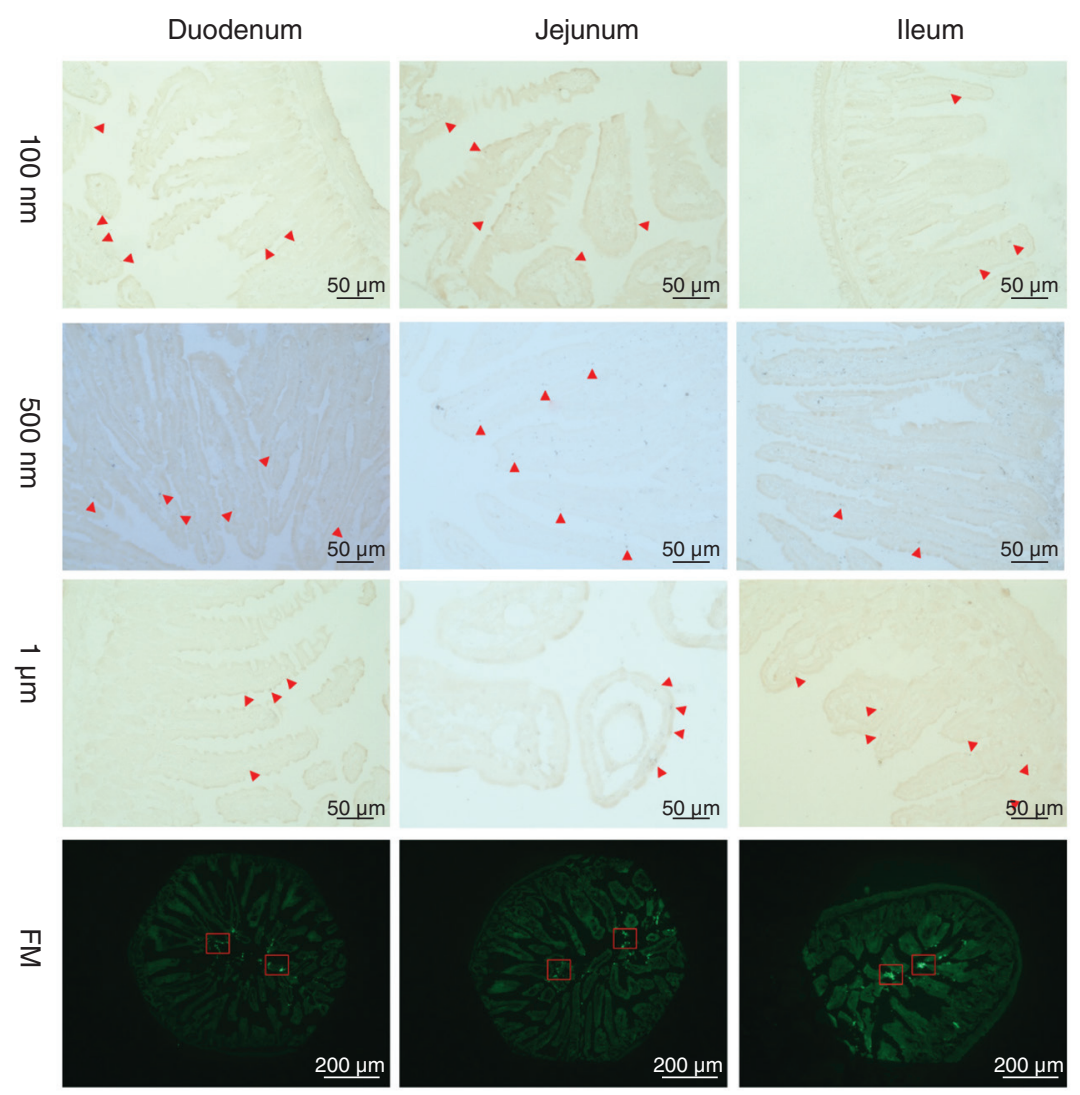

Figure 5. Localization of $100 \mathrm{~nm}, 500 \mathrm{~nm}, 1 \mu \mathrm{m}$ DSP, and FM in the small intestine after $2 \mathrm{~h}$ uptake. Red arrows indicate positive signals, while red boxes are the fluorescent microsphere signals.

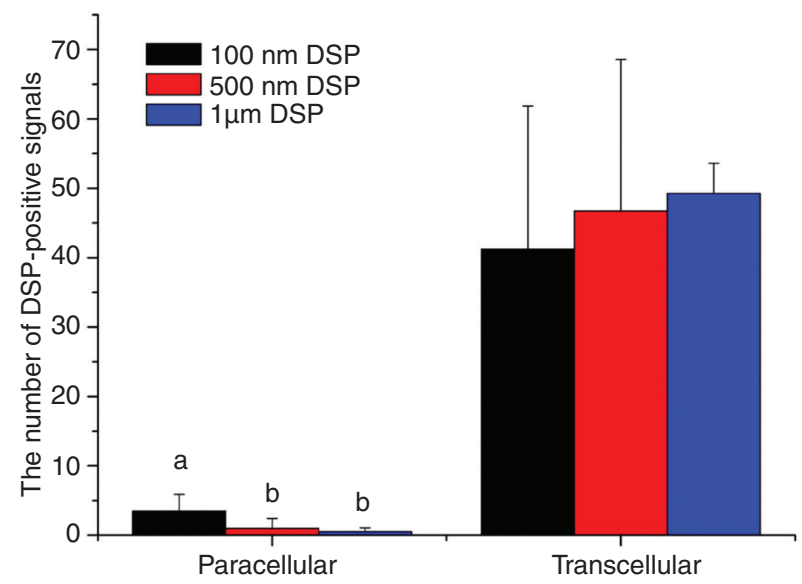

Figure 6. Semiquantitative analysis of DSP-positive staining in small intestine. Letters $a$ and $b$ indicate statistical difference among the three groups.

$\mathrm{BW}$ gain and relative organ weights between treated and control mice (Table 2).

To study whether each DSP causes in vivo acute toxicity, the organs of mice in each treatment group were excised and sectioned for H\&E staining at $24 \mathrm{~h}$. No noticeable tissue damage or inflammatory lesion were found in the organs from all the treatment groups of female/male mice, except for a mild lesion in the spleen of male mice treated with $100 \mathrm{~nm}$ DSP (Supplementary Figure S6).

\section{Discussion}

Being used as food and feed for hundreds of years, defatted soybean is obviously a safe food. The aim of this research was to evaluate the safety of DSP, especially in nano size, namely, safety of its nanofabrication. DSPs of different sizes were prepared in this study. Following Wu et al. (2011), the particle size could reach as small as 100 $\mathrm{nm}$, namely, nDSP. Three sizes of DSP were prepared to detect the toxicity of DSP, and no toxicity was found for any of them.

No toxicity of nDSP was found in either the cell model or the animal model. This study revealed the absence of negative effects on cell viability via the CCK- 8 assay. The cell viability of $100 \mathrm{~nm}$ DSP increased with the concentration, and it was higher than those of $500 \mathrm{~nm}$ and $1 \mu \mathrm{m}$ DSPs. The 
Table 2. Relative organ weight (\%) after oral administration of defatted soybean particles of different sizes.

\begin{tabular}{lcccccc} 
& N & Liver (\%) & Spleen(\%) & Lung (\%) & Kidney (\%) & Small intestine (\%) \\
\hline Females & & & & & & \\
$\quad$ Control & 3 & $5.6 \pm 0.48$ & $0.44 \pm 0.1$ & $0.72 \pm 0.09$ & $1.31 \pm 0.13$ & $5.6 \pm 0.77$ \\
$100 \mathrm{~nm}$ DSP & 3 & $5.8 \pm 0.87$ & $0.41 \pm 0.08$ & $0.79 \pm 0.22$ & $1.5 \pm 0.09$ & $4.9 \pm 0.44$ \\
$500 \mathrm{~nm}$ DSP & 3 & $5.3 \pm 0.19$ & $0.49 \pm 0.11$ & $0.91 \pm 0.38$ & $1.35 \pm 0.17$ & $6.4 \pm 0.2$ \\
Ordinary DSP & 3 & $5.4 \pm 0.14$ & $0.47 \pm 0.02$ & $0.68 \pm 0.08$ & $1.26 \pm 0.07$ & $5.8 \pm 0.97$ \\
Males & & & & & \\
Control & 3 & $5.8 \pm 0.28$ & $0.35 \pm 0.09$ & $0.57 \pm 0.17$ & $1.9 \pm 0.06$ & $10.9 \pm 1.4$ \\
$100 \mathrm{~nm}$ DSP & 3 & $6.8 \pm 0.85$ & $0.48 \pm 0.03$ & $0.64 \pm 0.08$ & $2.0 \pm 0.21$ & $9.1 \pm 1.7$ \\
$500 \mathrm{~nm}$ DSP & 3 & $5.9 \pm 0.8$ & $0.36 \pm 0.04$ & $0.52 \pm 0.03$ & $1.8 \pm 0.06$ & $9.7 \pm 1.0$ \\
Ordinary DSP & 3 & $6.0 \pm 0.33$ & $0.42 \pm 0.08$ & $0.65 \pm 0.05$ & $1.8 \pm 0.18$ & $9.6 \pm 2.5$ \\
\hline
\end{tabular}

concentration of DSP used here reached their highest concentration, which is tens time of that previously reported (Ma et al. 2013), no cell toxicity was found. Caco-2 cells were frequently chosen in biosafety studies (Zhang et al. 2017), but simple toxicity data from cell lines are not enough to understand the full impact of NPs (Lopes et al. 2016).

Herein, the Balb-c mice model was applied for advance study. In general, when animals are exposed to harmful toxins, noticeable changes in weight gain (Meggs and Brewer 2007), liver coefficients, and feed efficiency (Cui et al. 2011) occur. In toxicity studies, BW gain or relative organs' weights indicated the toxic effect and target organ injury (Michael et al. 2007; Ugwah-Oguejiofor et al. 2019). For the target organs, a weight/size increase suggests the occurrence of hypertrophy, whereas a decrease suggests necrosis (Teo et al. 2002). The results found no statistically significant differences for all those weights and sizes in DSP-treated groups, compared with the control group. Balb-c mice models were commonly used in biological studies (Hillyer and Albrecht 2001), while other mice like C57BL and KM mice were also helpful in biosafety and toxicity studies, as they might offer information on diverse biosafety aspects (Smith et al. 2018; Zhang et al. 2017).

The large intestine receives liquid residue after digestion and absorption; this residue consists mostly of water and materials that were not digested or absorbed (Liao et al. 2010). In this study, low DSP levels in the large intestine were found in 100 and $500 \mathrm{~nm}$ DSPs, indicating that the percentage of unabsorbed DSP was lower in 100 and 500 $\mathrm{nm}$ DSPs than that in $1 \mu \mathrm{m}$ DSPs. Thus, the amount of DSP absorbed increased when the particle size was small.

Small particles induce high cytotoxicity due to their high surface area and other physicochemical properties (Cai et al. 2011; Gandamalla et al. 2019; Lopes et al. 2016), but the same cytotoxicity was not observed in $100 \mathrm{~nm}$ DSPs. Similar to silicon (Zhang et al. 2017), although nDSP is an NP with a size of about $100 \mathrm{~nm}$ in DLS and EM, the particles aggregate to microclusters in PBS. As the particle size of DSP decreases, the $\zeta$-potential decreases, while the aggregation potential increases (Wu et al. 2008). By using the laser particle size analyzer, it was found that the $\zeta$-potential of 100 and $500 \mathrm{~nm}$ DSPs was higher than $-30 \mathrm{mV}$, which made the particles to tend to aggregation. Fortunately, the aggregates with large diameters eliminated the possibility of toxicity induced by low particle size. Meanwhile, the toxicity of NPs is the result of either extracellular or intracellular NP dissolution (Singh and Ramarao 2012; Wang et al. 2014). DSP is hydrophilic, and it can dissolve in water even after aggregating into clusters. Thus, in the gastrointestinal tract stained by H\&E, no harm was found on the gastrointestinal tract.

The absorbance of DSP is dependent on the particle size, and the absorption path of nDSP might include intercellular absorption. As reported, small particles have a higher cell transport rate (Zhang et al. 2017), and the Papp coefficient of DSP increased with decreasing size. Although $100 \mathrm{~nm}$ DSP had the highest cell transport rate, its accumulation in the gastrointestinal tract was higher than $1 \mu \mathrm{m}$ DSP but less than $500 \mathrm{~nm}$ DSP. The agglomeration behavior and effective particle size within the gastrointestinal tract may play a major role in the oral bioavailability of nanomaterials (Hinkley et al. 2015). In immunoelectron microscopy, DSPs of $100 \mathrm{~nm}$ were localized paracellularly, and their intestinal absorption may occur paracellularly by persorption through gaps created by extruding enterocytes (Hillyer and Albrecht 2001). However, the difference was not significant, and further studies are needed to verify these findings.

\section{Conclusions}

DSPs are safe at a single dose of $10 \mathrm{~g} / \mathrm{kg}$ BW, regardless of the particle size. The nDSPs could be absorbed more 
quickly than large DSPs, but both had similar distribution patterns. The agglomeration behavior, as well as food property, might make the NPs safe and affect their absorption.

\section{Acknowledgements}

This research was supported by the National Natural Science Foundation of China (No. 31260411), with the Funding for Academic and Technical Leaders in Major Disciplines, Jiangxi Province, China (No. 20172BCB22003).

\section{Data availability statement}

The research data used to support the findings of this study are included within the article and the supplementary information file (Figures S1-S6).

\section{References}

Abudayyak M, Gurkaynak TA, Ozhan G. In vitro evaluation of cobalt oxide nanoparticle-induced toxicity. Toxicol Indust Health. 2017;33:646-54. http://dx.doi.org/ $10.1177 / 0748233717706633$

Bihari P, Vippola M, Schultes S, Praetner M, Khandoga AG, Reichel $\mathrm{CA}$, et al. Optimized dispersion of nanoparticles for biological in vitro and in vivo studies. Part Fibre Toxicol. 2008;5:14. http:// dx.doi.org/10.1186/1743-8977-5-14

Bitencourt PER, Ferreira LM, Cargnelutti LO, Denardi L, Boligon A, Fleck $\mathrm{M}$, et al. A new biodegradable polymeric nanoparticle formulation containing Syzygium cumini: Phytochemical profile, antioxidant and antifungal activity and in vivo toxicity. Indust Crops Products. 2016;83:400-7. http://dx.doi.org/10.1016/j. indcrop.2016.01.007

Boyles MS, Ranninger C, Reischl R, Rurik M, Tessadri R, Kohlbacher O, et al. Copper oxide nanoparticle toxicity profiling using untargeted metabolomics. Part Fibre Toxicol. 2016;13:49. http://dx.doi.org/10.1186/s12989-016-0160-6

Brenner SA, Neu-Baker NM, Caglayan C, Zurbenko IG. Occupational exposure to airborne nanomaterials: An assessment of worker exposure to aerosolized metal oxide nanoparticles in semiconductor wastewater treatment. J Occup Environ Hyg. 2015;12:469-81. http://dx.doi.org/10.1080/15459624.2015.1018515

Cai K, Hou Y, Hu Y, Zhao L, Luo Z, Shi Y, et al. Correlation of the cytotoxicity of $\mathrm{TiO} 2$ nanoparticles with different particle sizes on a sub-200-nm scale. Small. 2011;7:3026-31. http://dx.doi. org/10.1002/smll.201101170

Cui Y, Liu H, Zhou M, Duan Y, Li N, Gong X, et al. Signaling pathway of inflammatory responses in the mouse liver caused by TiO2 nanoparticles. J Biomed Mater Res A. 2011;96:221-9. http://dx.doi.org/10.1002/jbm.a.32976

Frey A, Giannasca KT, Weltzin R, Giannasca PJ, Reggio H, Lencer WI, et al. Role of the glycocalyx in regulating access of microparticles to apical plasma membranes of intestinal epithelial cells: Implications for microbial attachment and oral vaccine targeting. J Exp Med. 1996;184:1045-59. http://dx.doi. org/10.1084/jem.184.3.1045

Gandamalla D, Lingabathula H, Yellu N. Nano titanium exposure induces dose- and size-dependent cytotoxicity on human epithelial lung and colon cells. Drug Chem Toxicol. 2019;42(1):2434. http://dx.doi.org/10.1080/01480545.2018.1452930

Graham UM, Jacobs G, Yokel RA, Davis BH, Dozier AK, Birch ME, et al. From dose to response: In vivo nanoparticle processing and potential toxicity. Adv Exp Med Biol. 2017;947:71-100. http:// dx.doi.org/10.1007/978-3-319-47754-1_4.

Hillyer JF, Albrecht RM. Gastrointestinal persorption and tissue distribution of differently sized colloidal gold nanoparticles. J Pharm Sci. 2001;90:1927-36. http://dx.doi.org/10.1002/ jps.1143

Hinkley GK, Carpinone P, Munson JW, Powers KW, Roberts SM. Oral absorption of PEG-coated versus uncoated gold nanospheres: Does agglomeration matter? Part Fibre Toxicol. 2015;12:9. http://dx.doi.org/10.1186/s12989-015-0085-5

Jani PU, Florence AT, Mccarthy DE. Further histological evidence of the gastrointestinal absorption of polystyrene nanospheres in the rat. Int J Pharmaceut. 1992;84:245-52. http://dx.doi. org/10.1016/0378-5173(92)90162-U

Jeevanandam J, Barhoum A, Chan YS, Dufresne A, Danquah MK. Review on nanoparticles and nanostructured materials: History, sources, toxicity and regulations. Beilstein J Nanotechnol. 2018;9:1050-74. http://dx.doi.org/10.3762/bjnano.9.98

Jia XL, Li SY, Dang SS, Cheng YA, Zhang X, Wang WJ, et al. Increased expression of chondroitin sulphate proteoglycans in rat hepatocellular carcinoma tissues. World J Gastroenterol. 2012;18:3962-76. http://dx.doi.org/10.3748/wjg.v18.i30.3962

Lacroix IME, Chen XM, Kitts DD, Li-Chan ECY. Investigation into the bioavailability of milk protein-derived peptides with dipeptidylpeptidase IV inhibitory activity using Caco-2 cell monolayers. Food Funct. 2017;8:701-9. http://dx.doi.org/10.1039/C6FO01411A

Lanone S, Boczkowski J. Biomedical applications and potential health risks of nanomaterials: Molecular mechanisms. Curr Mol Med. 2006;6:651-63. http://dx.doi.org/10.2174/156652406778195026

Leung YH, Yung MM, Ng AM, Ma AP, Wong SW, Chan CM, et al. Toxicity of $\mathrm{CeO}_{2}$ nanoparticles - The effect of nanoparticle properties. J Photochem Photobiol B. 2015;145:48-59. http:// dx.doi.org/10.1016/j.jphotobiol.2015.01.017

L'Hocine L, Boye JI. Allergenicity of soybean: New developments in identification of allergenic proteins, cross-reactivities and hypoallergenization technologies. Crit Rev Food Sci Nutr. 2007;47:127-43. http://dx.doi.org/10.1080/10408390600626487

Li JQ, Zou XW, Li CL, Zhong JH, Chen Y, Zhang XY, et al. Expression of novel cancer/testis antigen TMEM31 increases during metastatic melanoma progression. Oncol Lett. 2017;13:2269-73. http://dx.doi.org/10.3892/ol.2017.5728

Liao CD, Hung WL, Lu WC, Jan KC, Shih DYC, Yeh AI, et al. Differential tissue distribution of sesaminol triglucoside and its metabolites in rats fed with lignan glycosides from sesame meal with or without nano/submicrosizing. J Agric Food Chem. 2010;58:563-9. http://dx.doi.org/10.1021/jf9028046 
Lopes VR, Loitto V, Audinot JN, Bayat N, Gutleb AC, Cristobal S. Dose-dependent autophagic effect of titanium dioxide nanoparticles in human $\mathrm{HaCaT}$ cells at non-cytotoxic levels. J Nanobiotechnol. 2016;14:22. http://dx.doi.org/10.1186/ s12951-016-0174-0

Lusas EW, Riaz MN. Soy protein products: Processing and use. J Nutr. 1995;125:573S-80S.

Ma JQ, Guan RF, Shen HT, Lu F, Xiao CG, Liu MQ, et al. Comparison of anticancer activity between lactoferrin nanoliposome and lactoferrin in Caco-2 cells in vitro. Food Chem Toxicol. 2013;59:72-7. http://dx.doi.org/10.1016/j.fct.2013.05.038

Maurer LL, Yang XY, Schindler AJ, Taggart RK, Jiang CJ, Hsu-Kim H, et al. Intracellular trafficking pathways in silver nanoparticle uptake and toxicity in Caenorhabditis elegans. Nanotoxicology. 2016;10:831-835. http://dx.doi.org/10.3109/17435390.2015.1110759

Meggs WJ, Brewer KL. Weight gain associated with chronic exposure to chlorpyrifos in rats. J Med Toxicol. 2007;3:89-93. http:// dx.doi.org/10.1007/BF03160916

Michael B, Yano B, Sellers RS, Perry R, Morton D, Roome N, et al. Evaluation of organ weights for rodent and non-rodent toxicity studies: A review of regulatory guidelines and a survey of current practices. Toxicol Pathol. 2007;35:742-50. http://dx.doi. org/10.1080/01926230701595292

Nohynek GJ, Dufour EK, Roberts MS. Nanotechnology, cosmetics and the skin: Is there a health risk? Skin Pharmacol Physiol. 2008;21:136-49. http://dx.doi.org/10.1159/000131078

Pakrashi S, Tan C, Wang WX. Bioaccumulation-based silver nanoparticle toxicity in Daphnia magna and maternal impacts. Environ Toxicol Chem. 2017;36:3359-66. http://dx.doi. org/10.1002/etc.3917

Parhi R, Suresh P. Preparation and characterization of solid lipid nanoparticles - A review. Curr Drug Discov Technol. 2012;9:216. http://dx.doi.org/10.2174/157016312799304552

Park EJ, Lee GH, Yoon C, Jeong U, Kim Y, Chang J, et al. Tissue distribution following 28 day repeated oral administration of aluminum-based nanoparticles with different properties and the in vitro toxicity. J Appl Toxicol. 2017;37:1408-19. http://dx.doi. org/10.1002/jat.3509

Patel MR, San Martin-Gonzalez MF. Characterization of ergocalciferol loaded solid lipid nanoparticles. J Food Sci. 2012;77:N8-13. http://dx.doi.org/10.1111/j.1750-3841.2011.02517.x

Qu DF, Gu YP, Feng LF, Han JZ. High content analysis technology for evaluating the joint toxicity of sunset yellow and sodium sulfite in vitro. Food Chem. 2017;233:135-43. http://dx.doi. org/10.1016/j.foodchem.2017.04.102

Recordati C, De Maglie M, Bianchessi S, Argentiere S, Cella C, Mattiello S, et al. Tissue distribution and acute toxicity of silver after single intravenous administration in mice: Nano-specific and size-dependent effects. Part Fibre Toxicol. 2016;13:12. http://dx.doi.org/10.1186/s12989-016-0124-x

Singh RP, Ramarao P. Cellular uptake, intracellular trafficking and cytotoxicity of silver nanoparticles. Toxicol Lett. 2012;213:24959. http://dx.doi.org/10.1016/j.toxlet.2012.07.009

Smith JN, Thomas DG, Jolley H, Kodali VK, Littke MH, Munusamy P, et al. All that is silver is not toxic: Silver ion and particle kinetics reveals the role of silver ion aging and dosimetry on the toxicity of silver nanoparticles. Part Fibre Toxicol. 2018;15:47. http://dx. doi.org/10.1186/s12989-018-0283-Z

Tang QJ, Tao KZ, Yun L, Sun XJ, Geng MY, Jiang CL. Immunocytochemical localization of secretory component in Paneth cell secretory granules-rat Paneth cells participate in acquired immunity. J Mol Histol. 2005;36:331-5. http://dx.doi. org/10.1007/s10735-005-9003-8

Teo S, Stirling D, Thomas S, Hoberman A, Kiorpes A, Khetani V. A 90-day oral gavage toxicity study of D-methylphenidate and D,Lmethylphenidate in Sprague-Dawley rats. Toxicology. 2002;179:18396. http://dx.doi.org/10.1016/S0300-483X(02)00338-4.

Ugwah-Oguejiofor CJ, Okoli CO, Ugwah MO, Umaru ML, Ogbulie CS, Mshelia HE, et al. Acute and sub-acute toxicity of aqueous extract of aerial parts of Caralluma dalzielii N. E. Brown in mice and rats. Heliyon. 2019;5:e01179. http://dx.doi.org/10.1016/j. heliyon.2019.e01179

van Pomeren M, Peijnenburg W, Brun NR, Vijver MG. A novel experimental and modelling strategy for nanoparticle toxicity testing enabling the use of small quantities. Int J Environ Res Public Health. 2017;14:1348. http://dx.doi.org/10.3390/ ijerph14111348

Vance ME, Kuiken T, Vejerano EP, McGinnis SP, Hochella MF Jr., Rejeski D, et al. Nanotechnology in the real world: Redeveloping the nanomaterial consumer products inventory. Beilstein J Nanotechnol. 2015;6:1769-80. http://dx.doi.org/10.3762/bjnano.6.181

Wang T, Qin GX, Sun ZW, Zhao Y. Advances of research on glycinin and beta-conglycinin: A review of two major soybean allergenic proteins. Crit Rev Food Sci Nutr. 2014;54:850-62. http:// dx.doi.org/10.1080/10408398.2011.613534

Wang X, Ji Z, Chang CH, Zhang H, Wang M, Liao YP, et al. Use of coated silver nanoparticles to understand the relationship of particle dissolution and bioavailability to cell and lung toxicological potential. Small. 2014;10:385-98. http://dx.doi.org/10.1002/ smll.201301597

Wassef L, Quadro L. Uptake of dietary retinoids at the maternalfetal barrier: In vivo evidence for the role of lipoprotein lipase and alternative pathways. J Biol Chem. 2011;286:32198-207. http://dx.doi.org/10.1074/jbc.M111.253070

Wu Z, Chen H, Wu L, Yang A, Li X. The method for nano defatted soybean particles manufacture. SIPO of China, ZL 20091 0132261.8, 2011.

Wu Z, Lin Q, Mao H, Yang A, Chen H. The particle size and aggregation of soybean powder after milling. Food Sci (Chinese). 2008;29:315-17.

Zhang Y, Chen X, Zhao B, Wu H, Yuan L, Zhang H, et al. Biosafety study and mechanism comparison on two types of silica with different nanostructures. Toxicol Res (Camb). 2017;6:487-98. http://dx.doi.org/10.1039/C7TX00076F

Zhao J, Castranova V. Toxicology of nanomaterials used in nanomedicine. J Toxicol Environ Health B Crit Rev. 2011;14:593-632. http://dx.doi.org/10.1080/10937404.2011.615113

Zhao Y, Wang C, Chow AH, Ren K, Gong T, Zhang Z, et al. Selfnanoemulsifying drug delivery system (SNEDDS) for oral delivery of Zedoary essential oil: Formulation and bioavailability studies. Int J Pharm. 2010;383:170-7. http://dx.doi. org/10.1016/j.ijpharm.2009.08.035 


\section{Supplement}

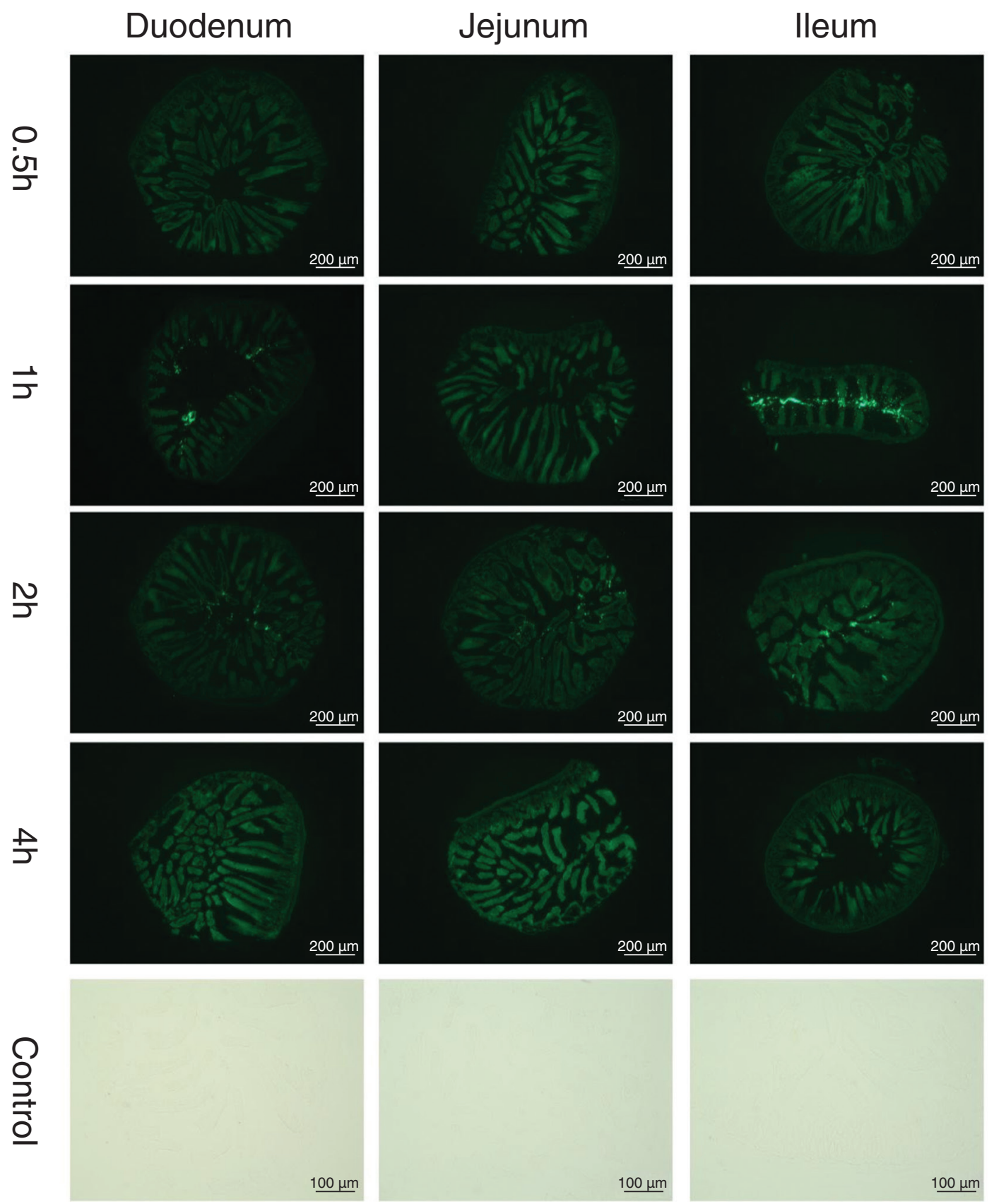

Figure S1. Location of fluorescent microspheres in the small intestine of mice after uptake; The bright green is the fluorescent microsphere signal. 


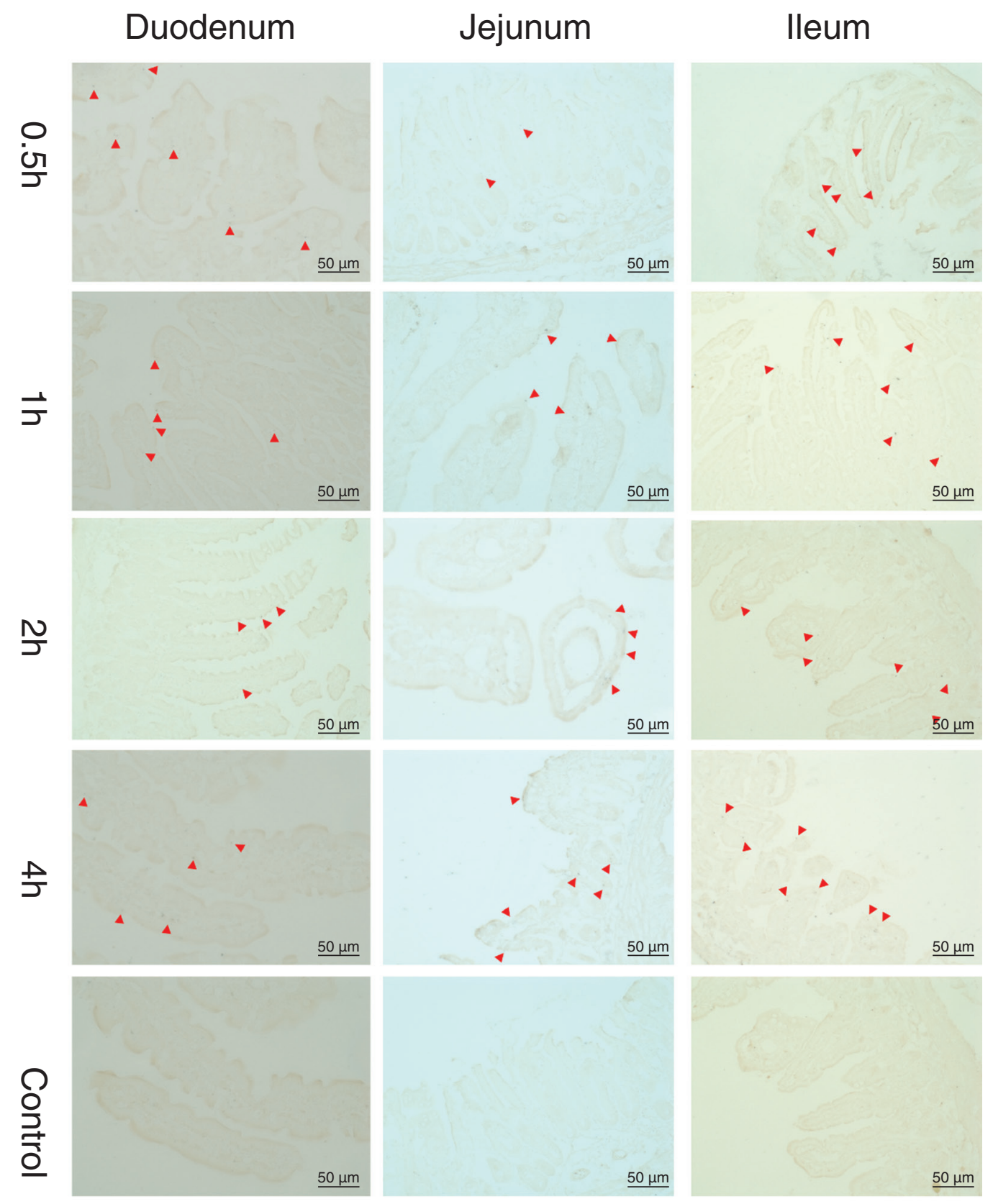

Figure S2. Localization of ordinary DSP in the intestinal tract of mice after uptake. Representative images of duodenum, jejunum, ileum, from control, ordinary DSP-treated mice at different time period. Red arrows indicate positive signals. 


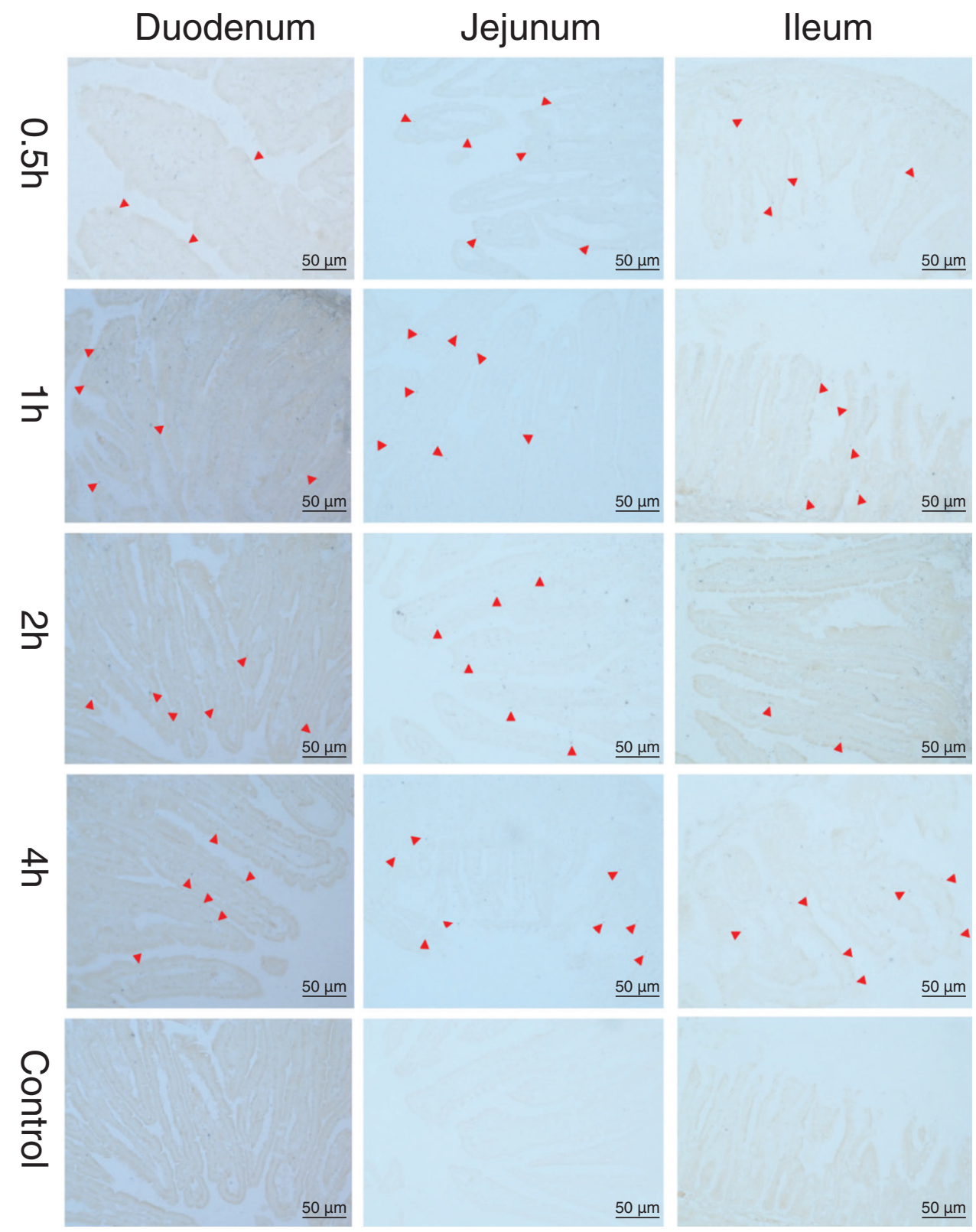

Figure S3. Localization of $500 \mathrm{~nm}$ DSP in the intestinal tract of mice after uptake. Representative images of duodenum, jejunum, ileum, from control, $500 \mathrm{~nm}$ DSP-treated mice at different time period. Red arrows indicate positive signals. 
Tong S et al.

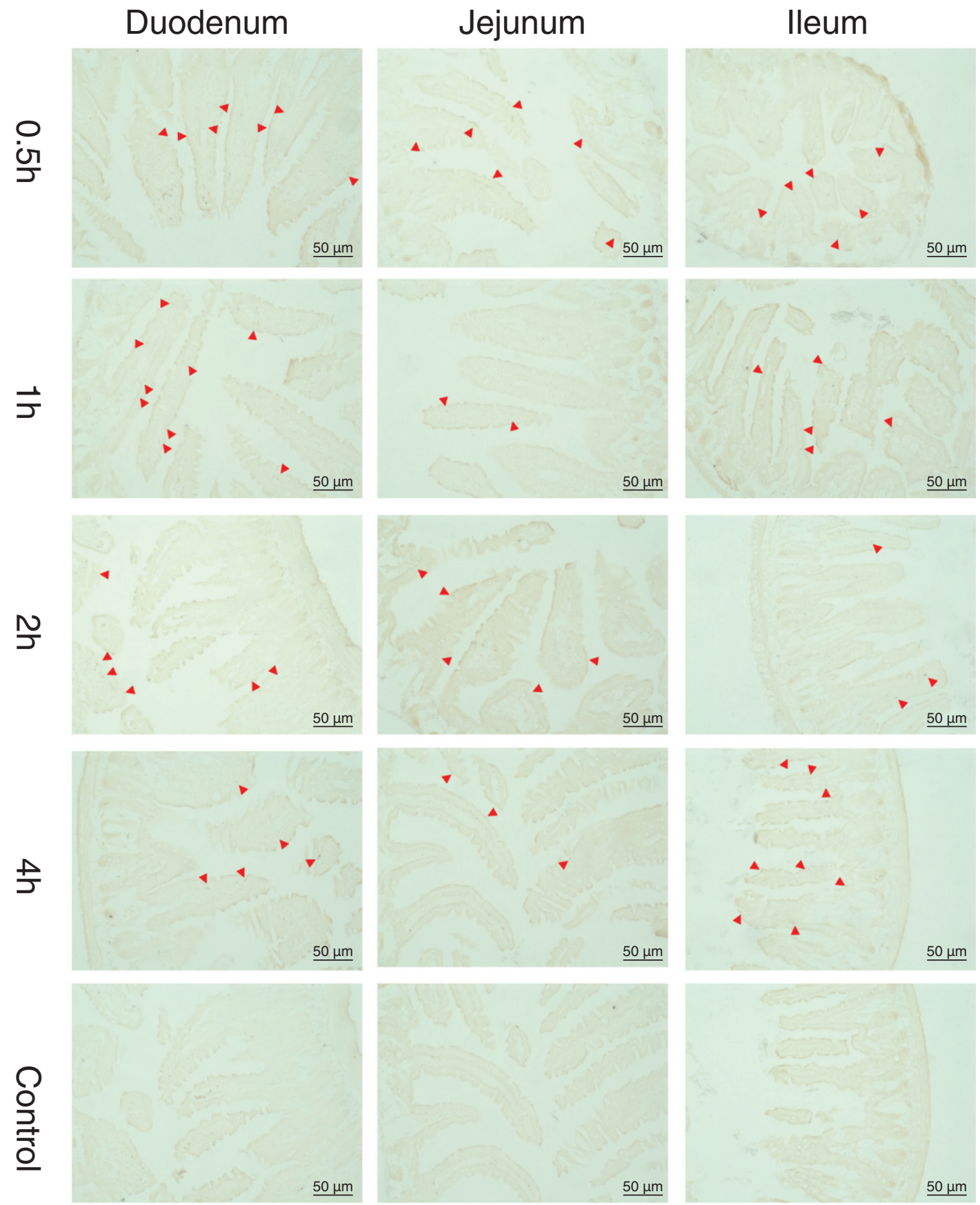

Figure S4. Localization of $100 \mathrm{~nm}$ DSP in the intestinal tract of mice after uptake. Representative images of duodenum, jejunum, ileum, from control, $100 \mathrm{~nm}$ DSP-treated mice at different time period. Red arrows indicate positive signals. 


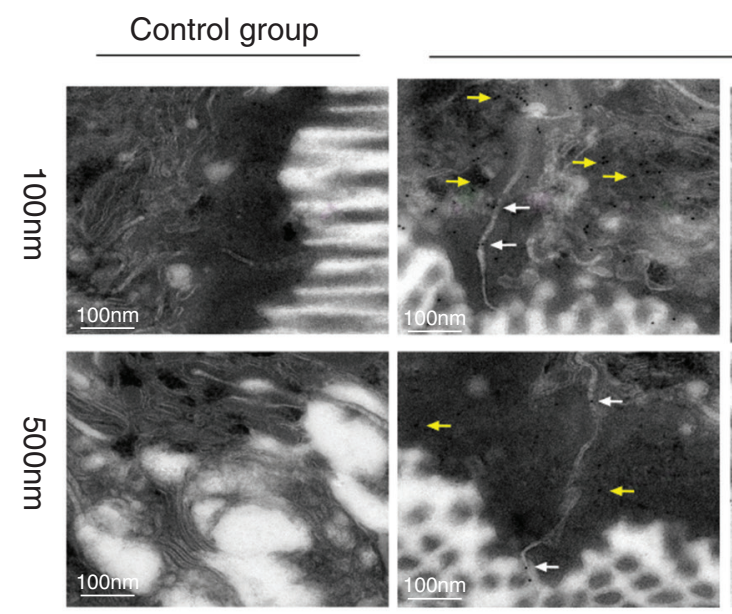

Experiment group
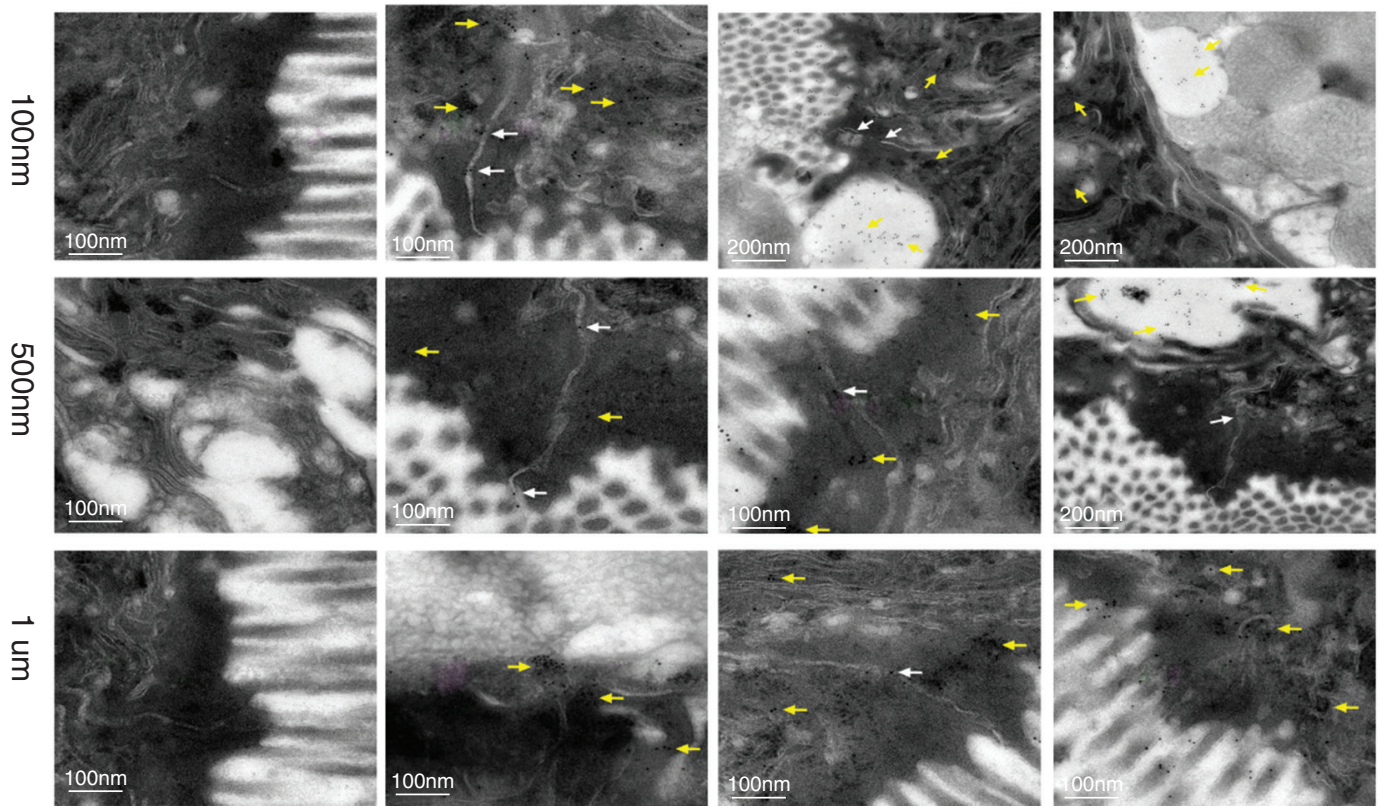

Figure S5. Localization of $100 \mathrm{~nm}, 500 \mathrm{~nm}, 1 \mu \mathrm{m}$ DSP in the intestinal tract by immunoelectron microscopy. Most of DSP (yellow arrows) are found within the cytoplasm of epithelial cells. Rarely, small numbers of DSP are found within tight junction (white arrows).

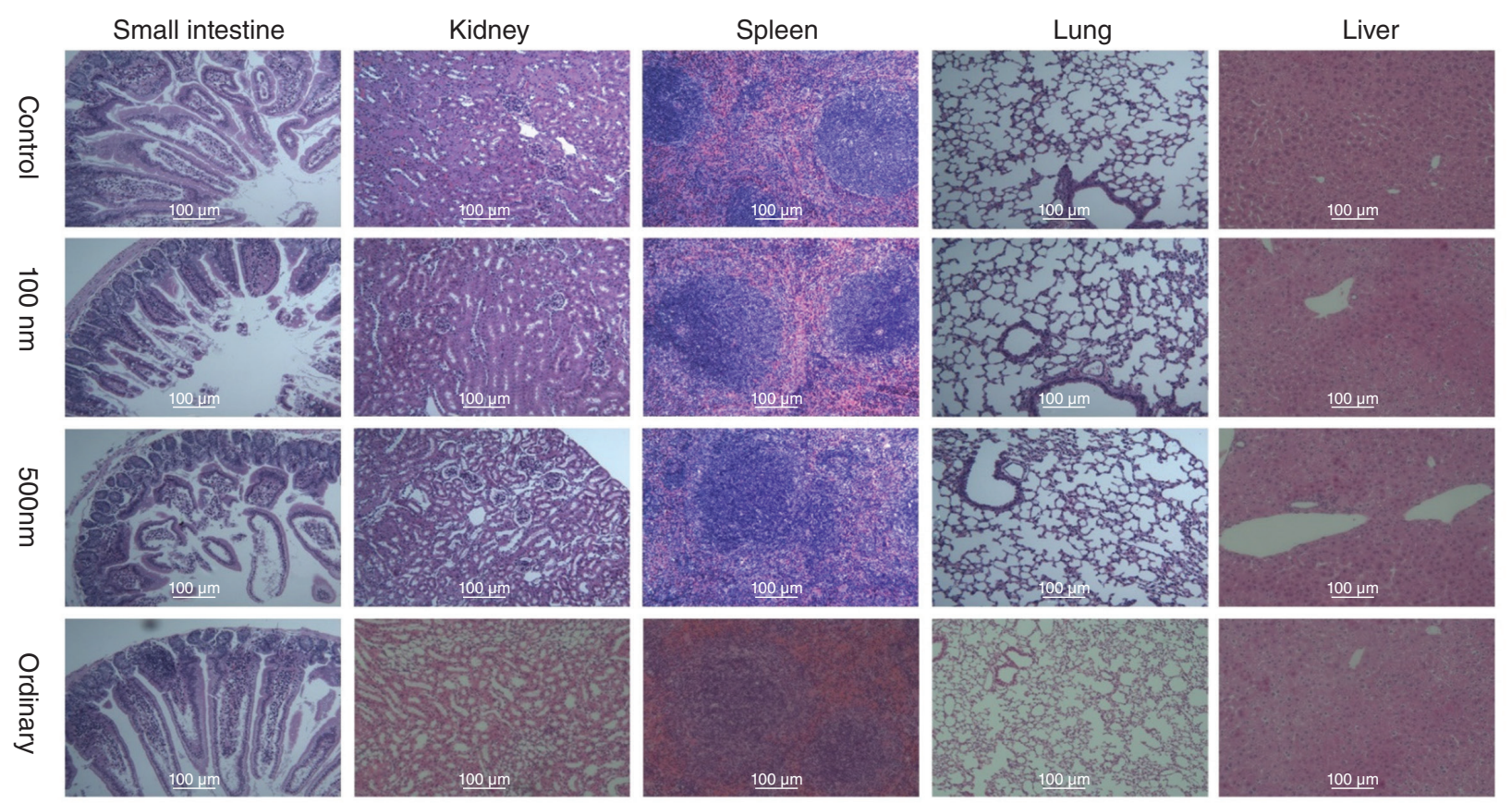

Figure S6. Histological evaluation of adverse effects after intragastrical administration of nano defatted soybean particles in female mice. 